\title{
CYTOTOXIC EFFECT OF CORCHORUS DEPRESSUS AGAINST HEPG2 AND HLE HUMAN LIVER CANCER CELLS
}

\author{
PURVI H KAKRANI ${ }^{1}$, HARISH N KAKRANI ${ }^{1}$, MANAN RAVAL ${ }^{2 *}$
}

${ }^{1}$ Department of Pharmacognosy, Shivam Pharmaceutical Studies and Research Center, Anand, Gujarat, India. ${ }^{2}$ Department of Pharmacognosy, Ramanbhai Patel College of Pharmacy, Charotar University of Science and Technology, Charusat Campus, Anand, Gujarat, India.

Email: mananraval.ph@charusat.ac.in

Received: 14 June 2018, Revised and Accepted: 27 July 2018

ABSTRACT

Objective: The present study was designed to examine the cytotoxic effects of methanolic extract of aerial parts of Corchorus depressus and hexane, chloroform, ethyl acetate, and aqueous fractions of the same extract in the human hepatocellular carcinoma (HCC) (HepG2) and invasive hepatocellular carcinoma cell lines (HLE).

Methods: Anti-proliferative effects were evaluated using 3-(4,5-dimethythiazol2-yl)-2,5-diphenyl tetrazolium bromide (MTT) and neutral red uptake (NRU) assay. Human HCC (HepG2) and invasive hepatocellular carcinoma cell lines (HLE) were treated with different concentrations of methanolic extract $(10,25,50,100,200,300,400$, and $500 \mu \mathrm{g} / \mathrm{mL})$ of aerial parts of C. depressus as well as hexane, chloroform, ethyl acetate, and aqueous fractions $(200 \mu \mathrm{g} / \mathrm{mL})$ for 24 and $48 \mathrm{~h}$. The cell viability and the half maximal inhibitory concentration (IC $\left.{ }_{50}\right)$ were determined.

Results: The maximum cytotoxic effect was noticed with a maximum dose of methanolic extract (500 $\mu \mathrm{g} / \mathrm{mL})$ and alkaloidal fraction $(200 \mu \mathrm{g})$ in this study with an $\mathrm{IC}_{50}$ value of about $200 \mu \mathrm{g}$.

Conclusion: The set of studies showed that methanolic extract of aerial parts of $C$. depressus and alkaloidal, chloroform and ethyl acetate fractions fractions was capable of inhibiting cell growth and cell proliferation by inducing cytotoxicity of HepG2 and HLE cells.

Keywords: Liver cancer, HepG2 and HLE cell line, Corchorus depressus, Cytotoxicity, MTT, Neutral red uptake assay.

(C) 2018 The Authors. Published by Innovare Academic Sciences Pvt Ltd. This is an open access article under the CC BY license (http://creativecommons. org/licenses/by/4. 0/) DOI: http://dx.doi.org/10.22159/ajpcr.2018.v11i12.27937

\section{INTRODUCTION}

Hepatocellular carcinoma (liver cancer; HCC) is the fifth most common cancer worldwide now and causes significant public health problems, especially in association with chronic hepatitis B or C [1]. The liver functions to absorb and store nutrients, remove toxic waste and create clotting factors that stop bleeding from injuries. When HCC is present, the body exhibits symptoms such as drastic loss of weight, swelling in the abdomen, or jaundice [2]. The risk of developing liver cancer increases with factors associated with hepatitis B/C virus, aflatoxin, iron storage disease, cirrhosis, alcoholism, or obesity [3-5]. The average survival rate for hepatic cancer patients is $3-5 \%$ [6].

Corchorus depressus (Family Tiliaceae) (Cd) has been used in the indigenous system of medicine as a tonic, cooling medicine in fevers; its mucilage is prescribed in gonorrhea. Root is rubbed on stone and smeared over the forehead to get relief in migraine [7]. It is also used to increase the viscosity of the seminal fluid, to set-up menstrual disorder [8]. An extract of the plant is applied as a paste in the healing of wounds [9]. It has been used as antibacterial, antifungal, anthelmintic drug in folklore medicine [10], as antimalarial [11], has cardiotonic activity [12], as tonic [13], in the treatment of gonorrhea [14], as veterinary medicine [15] and possesses diuretic activity [16]. The plant is sweetish hot sharp acrid; removes tumors and pain; cures piles. It is given as a cooling medicine in fevers. The leaves are emollient. The seeds in decoction with milk and sugar are given as a tonic in Mahal Kohistan (Khirthar National Park) Pakistan [17].

C. depressus is reported to contain sitosterol, sitosterol glucoside, apigenin, luteolin, oleanolic acid, cordepressic acid, cordepressin, cordepressinic acid, $\alpha$ amyrin, kaempferol, etc., [18,19].

Lack of scientific data regarding antitumor properties of $C$. depressus (L.) prompted us to evaluate the claimed medicinal action.
Hepatic cancer is traditionally difficult to treat. Hence, the objectives of the current study were to (1) determine the in vitro cytotoxicity of $C d$ methanolic extract of aerial parts and its hexane, alkaloidal, chloroform, ethyl acetate and aqueous fractions, and aqueous fractions on HepG2 and HLE cancer cells and (2) determine the cytotoxicity of actinomycin, an FDA-approved drug, for various cancers, against HCC.

In light of some reports [20,21], it is reasonable to assume that this plant could have anticancer potential. Hence, in this study, we investigated the cytotoxic potential of $\mathrm{Cd}$ methanolic extract of aerial parts and its hexane, alkaloidal, chloroform, ethyl acetate and aqueous fractions, and aqueous fractions against human Hep G2 and HLE cancer cell lines.

\section{METHODS}

\section{Authentication of plant material}

The fully grown plants of $\mathrm{Cd}$ were collected from Adipur region of Kachchh district in the month of September. Their authentication was confirmed by Dr. Suman Chandra Sharma, Taxonomist, Department of Botany, Government Dungar College, Bikaner, Rajasthan, and its voucher specimen deposited this plant with the Department of Pharmacognosy, Ramanbhai Patel College of pharmacy, Changa (CHARUSAT).

\section{Cell culture}

The Hep G2 and HLE cells were cultured in Dulbecco's Modified Eagle medium supplemented with $10 \%$ of fetal bovine serum and $1 \%$ penicillin-streptomycin. Cell cultures were maintained at $37^{\circ} \mathrm{C}$ in a fully humidified atmosphere containing $5 \% \mathrm{CO}_{2}$.

\section{Cell treatment}

Cd dried aerial parts methanolic extract; hexane, alkaloidal, chloroform, ethyl acetate and aqueous fractions were dissolved in $0.1 \%$ dimethyl sulfoxide (DMSO) (v/v). HepG2 and HLE cells were plated at $1.2 \times 10^{4}$ cells / $\mathrm{cm}^{2} .24 \mathrm{~h}$ later, cells were fed with fresh expansion culture medium 
supplemented with different final concentrations of extract $(10,25,50$, $100,200,300,400$, and $500 \mu \mathrm{g} / \mathrm{mL}$ ) or the corresponding volumes of the vehicle. After $24 \mathrm{~h}$ of treatment cells were collected after $0.05 \%$ trypsin application. Cell viability was also evaluated by 3-(4,5-dimethylthiazol-2yl)-2,5- diphenyltetrazoliumbromide (MTT) and neutral red uptake (NRU) assay [22].

\section{MTT assay}

According to the method described by Borenfreund et al. [23], the growth of cancer cells was quantified. Following a $24 \mathrm{~h}$ exposure period of drugs, cells were washed twice with phosphate buffered saline (PBS), and a $10 \mu \mathrm{L}$ of MTT reagent ( $5 \mathrm{mg} / \mathrm{mL}$ in PBS) was added to each well including the blanks, which contained medium only. The plates were returned to the incubator for $4 \mathrm{~h}$ at $37^{\circ} \mathrm{C}$. Subsequently, cells were washed twice with PBS, and $100 \mu \mathrm{L} /$ well DMSO was added in each well as a solvent to dissolve the insoluble crystalline formazan products. The effect of plant extracts on cancer cells was quantified as the percentage of control absorbance of reduced dye at $550 \mathrm{~nm}$ on a microplate reader. For each treatment, five replicate wells were examined, and each experiment was repeated 3 times $(n=3)$. Mean and standard deviation was calculated between three experiments. Results were calculated as percentage growth inhibition, untreated (control) cells versus treated cells according to the following formula:

$$
\% \text { Growth inhibition }=\frac{\begin{array}{l}
\text { Absorbance of positive control }- \\
\text { Absorbance of test sample }
\end{array}}{\text { Absorbance of positive control }} \times 100
$$

Where,

Positive control $=$ absorbance of untreated cells after subtracting absorbance of media

Absorbance of test sample $=$ absorbance of treated cells at a particular concentration of testing sample after subtracting the absorbance of media.

The MTT cell proliferation assay measures the cell proliferation rate and conversely when metabolic events lead to apoptosis or necrosis, the reduction in cell viability. The number of assay steps has been minimized as much as possible to expedite sample processing. The MTT reagent yields low background absorbance values in the absence of cells. For each cell type, the linear relationship between cell number and signal produced is established, thus allowing accurate quantification of changes in the rate of cell proliferation [24].

\section{NRU assay}

The NRU assay was performed by removal of the medium after dosing cells, and $200 \mu \mathrm{L}$ of neutral red solution $(40 \mu \mathrm{g} / \mathrm{mL})$ was added to each well (including the blanks, which contained medium only). After incubation for $2.5 \mathrm{~h}$, the neutral red was removed, cells were carefully rinsed with pre-warmed PBS, and $200 \mu \mathrm{L}$ of ethanol/acetic acid (1\% glacial acetic acid in 5\% ethanol) was added to all wells.

The plates were covered in foil and placed on a plate shaker for $30 \mathrm{~min}$ to extract neutral red from the cells and form a homogeneous solution. The absorbance of the wells was measured at $540 \mathrm{~nm}$ in a microplate reader within $60 \mathrm{~min}$.

Cytotoxicity assays are widely used in toxicology studies. The NRU and 3-(4,5-dimethylthiazol-2-yl)-2,5- diphenyltetrazolium bromide (MTT) assays are commonly used cytotoxicity assays to determine the cytotoxic properties of compounds. NRU assay has been used as an indicator of cytotoxicity in cultures of primary hepatocytes [25] and other cell lines [26]. Living cells take up the neutral red, which is concentrated within the lysosomes of cells [27]. MTT, a watersoluble tetrazolium salt, is converted to insoluble purple formazan by cleavage of the tetrazolium ring by succinate dehydrogenase within the mitochondria. It is then solubilized in DMSO, and the cell viability depicts from its absorbance values [28].

\section{Statistical analysis}

In both the in vitro tests, statistical analysis was done by Dunnett's $t$-test. The data were expressed as mean \pm SEM. $p<0.05$ was considered as significant.

\section{RESULTS}

\section{Cytotoxic assay}

Cd methanolic extract caused dose-dependent increase in cytotoxicity in HepG2 and HLE human liver cancer cells. The maximum cytotoxic effect was noticed with the maximum dose used in this study, i.e., $500 \mu \mathrm{g} / \mathrm{mL}$ (Fig. 1). The extract showed an inhibitory concentration $\left(\mathrm{IC}_{50}\right)$ is about 200 $\mu \mathrm{g}$ (Fig. 1). The anti-proliferative activity was significantly concentrated in three fractions $(\mathrm{CHCl} 3$, EtOAc and alkaloidal, $\mathrm{n}=3$ for each fraction, mean \pm sd) with similar results obtained with the NRU assay. The alkaloidal fraction had the maximum effect on the cells. (Fig. 2).

\section{Cell viability}

We noticed that Cd treatment in HepG2 cells caused dose-dependent growth inhibition. Cytotoxic activity was determined by cell viability. The methanolic $\mathrm{Cd}$ aerial parts extract decreased the cell viability of HepG2 cancer cells prominently whereas in HLE the toxicity was quite less.

\section{DISCUSSION}

Chemoprevention is a novel approach emphasizing on the prevention or delay of carcinogenesis by means of pharmacological, biological, and nutritional intervention and recently, cancer chemoprevention with strategies using foods and medicinal herbs has been regarded as one of the most visible fields for cancer control [29]

Palliative treatments for HCC are indicated if there is no curative treatment option, four palliative treatments are transarterial chemo-embolization, systemic chemotherapy, interferon, and hormonotherapy [30]. However,

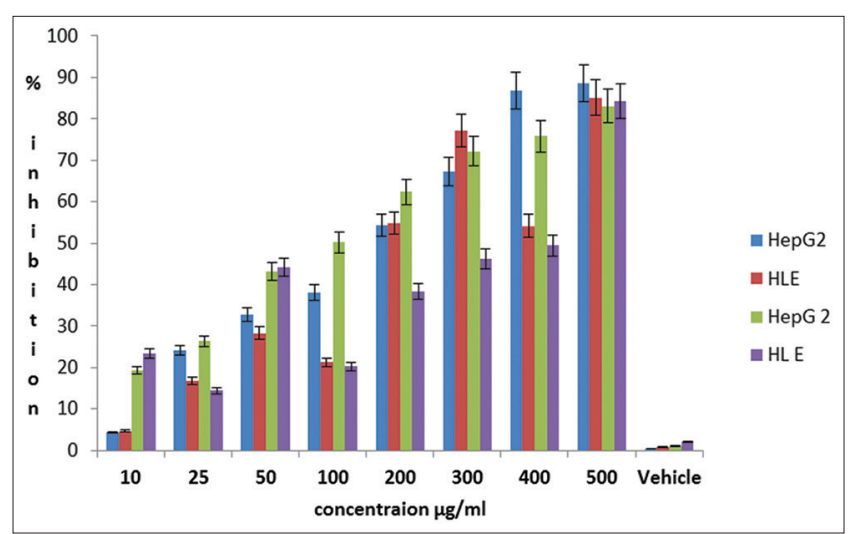

Fig. 1: Cytotoxicity activity of a methanolic crude extract of Corchorus depressus using MTT and neutral red uptake assay with apparent IC $_{50}$ about $200 \mu \mathrm{g} / \mathrm{mL}$ after $24 \mathrm{~h}$ of treatment \pm standard deviation

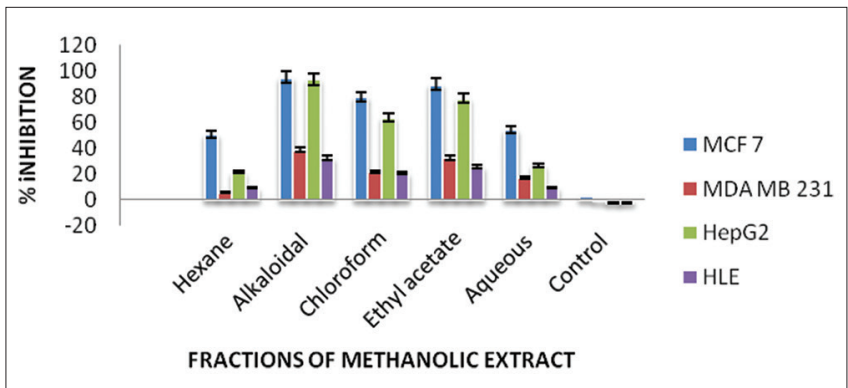

Fig. 2: Cytotoxic activity of fractions $(200 \mu \mathrm{g} / \mathrm{mL})$ from Corchorus depressus methanolic extract using MTT and NRU assay indicating the most potent fraction after $24 \mathrm{~h}$ treatment 
palliative therapy of patients with HCC remains challenging as HCC is highly resistant to systemic therapies. More importantly, the incidence still nearly equals the mortality rate and more than $80 \%$ of patients present with advanced disease [31]. The overall disappointing results of both curative therapies and palliative treatments in advanced HCC patients support the research for other more active and specific treatments to be administered alone or in combination with the current therapy. Herbal compounds could affect all phases of HCC, including initiation, promotion, and progression [32]. The active development of innovative therapeutic approaches and molecularly targeted agents using herbal medicine could offer an opportunity to study the agents in HCC and gives new hope for the future.

In vitro cytotoxicity studies are commonly performed to evaluate the anticancer potentials of a drug or plant extracts. In this study, we noticed the cytotoxic potential of $C d$ in human liver cancer cell line.

Some of the mutagenic and carcinogenic effects of various carboline alkaloids have been related to their ability to intercalate into DNA $[33,34]$ leading to altered DNA replication fidelity and enzymatic activities in DNA-repair processes $[35,36]$. They also significantly reduce cell proliferation [37]. In human neuroblastoma SH-SY5Y cells, some carboline alkaloids induced apoptosis as well as necrosis. Phytochemical evaluation of $\mathrm{Cd}$ has indicated the presence of $\beta$-carboline alkaloid/s so probably this cytotoxic effect of $c d$ may be by above-cited mechanism.

\section{ACKNOWLEDGMENTS}

The authors are grateful to Ramanbhai Patel College of Pharmacy and CHARUSAT and Shivam Education and Research Foundation Trust, for providing the necessary facilities to carry out the work.

\section{CONFLICTS OF INTEREST}

The authors declare that they have no conflicts of interest.

\section{AUTHORS' CONTRIBUTION}

Purvi Kakrani, Harish Kakrani, and Manan Raval contributed to the design and implementation of the research, to the analysis of the results and the writing of the manuscript.

\section{REFERENCES}

1. Kim DY, Han KH. Epidemiology and surveillance of hepatocellular carcinoma. Liver Cancer 2012;1:2-14.

2. Al-Sarraf M, Go TS, Kithier K, Vaitkevicius VK. Proceedings: Primary liver cancer. A review of the clinical features, blood groups, serum enzymes, therapy, and survival of 65 cases. Cancer 1999;33:574-82.

3. Bosch FX, Ribes J, Borràs J. Epidemiology of primary liver cancer. Semin Liver Dis 1999;19:271-85.

4. Pang R, Tse E, Poon RT. Molecular pathways in hepatocellular carcinoma. Cancer Lett 2006;240:157-69.

5. Neuschwander-Tetri BA, Caldwell SH. Nonalcoholic steatohepatitis: Summary of an AASLD single topic conference. Hepatology 2003;37:1202-19.

6. Edmondson HA, Steiner PE. Primary carcinoma of the liver: A study of 100 cases among 48,900 necropsies. Cancer 1954;7:462-503.

7. Upadhyay B, Parveen AK, Dharker AK. Ethnomedicinal and ethnopharmaco-statistical studies of Eastern Rajasthan, India. J Ethnopharmacol 2010;129:64-86,

8. Jain A, Katewa SS, Chaudhary BL, Galav P. Folk herbal medicines used in birth control and sexual diseases by tribals of Southern Rajasthan, India. J Ethnopharmacol 2004;90:171-7.

9. National Institute of Science Communication and Information Resources. The Wealth of India- A Dictionary of Indian Raw Materials and Industrial Products, Raw Materials. New Delhi: National Institute of Science Communication and Information Resources (CSIR); 1993. p. 195-200.

10. Naqvi SA, Khan MS, Vohora SB. Anti-bacterial, antifungal and anthelmintic investigation on Indian medicinal plants. Fitoterapia 1991;62:221-8.

11. Simonsen HT, Nordskjold JB, Smitt UW, Nyman U, Palpu CP, Joshi P, et al. In-vitro screening of Indian medicinal plants for antiplasmodial activity. J Ethnophamacol 2001;74:195-204.

12. Nyman U, Josh P, Madsen LB, Pedersen TB, Pinstrup M, Rajasekharan S, et al. Ethnomedical information and in vitro screening for angiotensin converting enzyme inhibition of plants utilized as traditional medicines in Gujarat, Rajasthan and Kerala (India). J Ethnophamacol 1998;60:247-63.

13. Jain A, Katewa SS, Galav PK, Sharma P. Medicinal plant diversity of Sitamata wildlife sanctuary, Rajasthan, India. J Ethno Pharm 2005; 102:143-57.

14. Singh AK, Raghubanshi AS, Singh JS. Medical ethnobotany of the tribal of Sonaghati of Sonbhadra district, Uttar Pradesh India. J Ethnopharmacol 2002;81:31-41.

15. Upadhyay B, Singh KP, Kumar A. Ethno-veterinary uses and informants consensus factor of Sariska region, Rajasthan, India. J Ethnopharmacol 2011;133:14-25.

16. Raza MA, Younas M, Buerkert A, Schlecht E. Ethno-botanical remedies used by pastoralists for the treatment of live stock diseases in Cholistan desert, Pakistan. J Ethnopharmacol 2013;13:774-5.

17. Panhwar AQ, Hidaytullah A. Ethnobotanical studies of Mahal Kohistan (Khirthar National Park). Pak J Bot 2007;39:2301-15.

18. Khan MS, Javed K, Khan MH, Shamsi MA, Siddique A. $\alpha$ amyrin derivatives from Corchorus depressus. Phytochem 1991;30:1989-92.

19. Harsh ML, Nag TN. Flavonoids with antimicrobial activity of arid zone plants. Geobios 1988;15:32-5

20. Kataria S, Kaur D, Rao SK, Sharma N, Khajuria RI. Hepatoprotective and in vivo antioxidant effects of Corchorus depressus (L.). Res J Pharm Tech 2012;5:1402-7.

21. Pareek A, Ashok G, Nagori BP. In vitro hepatoprotective activity of Corchorus depressus L. Against CCl4 induced toxicity in HepG2 cell line. Pharm J 2013;5:191-5.

22. Hailin YG, Ye J, Jiang X, Wu C. Anti-proliferative effect of allicin on human hepatoma HepG2 cells. Biomed Res 2016;27:195-8.

23. Borenfreund E, Babich H, Martin-Alguacil N. Comparisons of two in vitro cytotoxicity assays-the neutral red (NR) and tetrazolium MTT tests. Toxicol In Vitro 1988;2:1-6.

24. Available from: https://www.atcc.org/ /media/DA5285A1 F52C 414E864C966FD78C9A79.ashx

25. Fautz R, Husein B, Hechenberger C. Application of the neutral red assay (NR assay) to monolayer cultures of primary hepatocytes: Rapid colorimetric viability determination for the unscheduled DNA synthesis test (UDS). Mutat Res 1991;253:173-9.

26. Morgan CD, Mills KC, Lefkowitz DL, Lefkowitz SS. An improved colorimetric assay for tumor necrosis factor using WEHI 164 cells cultured on novel microtiter plates. J Immunol Methods 1991;145:259-62.

27. Fotakis G, Timbrell JA. In vitro cytotoxicity assays: Comparison of LDH, neutral red, MTT and protein assay in hepatoma cell lines following exposure to cadmium chloride. Toxicol Lett 2006;160:171-7.

28. Thangaraj P. Pharmacological Assays of Plant Based Natural Products. Switzerland: Springer International Publishing; 2016.

29. Dutta S, Deb N, Pattnaik AK, Besra SE. Apoptosis inducing potential of Lawsonia alba Lam. Leaves on hepatocellular carcinoma (HEP-G2) cells along with its anti-oxidant property. Int J Pharm Pharm Sci 2016;8:156-62.

30. Takayama T, Makuuchi M, Hirohashi S, Sakamoto M, Yamamoto J. Early hepato cellular carcinoma as an entity with a high rate of surgical cure. Hepatology 1998;28:1241-6.

31. Horgan AM, Dawson LA, Swaminath A, Knox JJ. Sorafenib and radiation therapy for the treatment of advanced hepatocellular carcinoma. J Gastrointest Cancer 2012;43:344-8.

32. Dey S, Roy S, Deb N, Sen KK, Besra SE. Anti-carcinogenic activity of Ruellia Tuberosa L. (Acanthaceae) leaf extract on hepatoma cell line and increased superoxide dismutase activity on macrophage cell lysate. Int J Pharm Pharm Sci 2013;5:854-61.

33. De Meester C. Genotoxic potential of b-carbolines: A review. Mutat Res 1995;339:139-53.

34. Taira Z, Kanzawas S, Dohara C, Ishida S, Matsumoto M, Sakiya Y. Intercalation of six beta-carboline derivatives into DNA. J Toxicol Environ Health 1997;43:83-91.

35. Funayama Y, Nishi K, Wakabayashi K, Nagao M, Simio K, Ohira T, et al. Effects of b- and g-carboline derivates on DNA topoisomerase activities. Mutat Res 1996;349:183-91.

36. Remsen JF, Cerutti PA. Inhibition of DNA-repair and DNA synthesis by Harman in human alveolar tumor cells. Biochem Biophys Res Commun 1979;86:124-9.

37. Lamchouri F, Settaf A, Cherrah Y, Zemzami M, Lyoussi B, Zaid A, et al. Antitumor principles from Peganum harmala seeds. Therapy 1999;54:753-8. 